\title{
Metabolite Production and Antibacterial Activities of Callus Cultures from Rosa damascena Mill. Petals
}

\author{
Pınar Olgunsoy, Seyhan Ulusoy, Ufuk Çelikkol Akçay
}

\begin{abstract}
Rosa damascena Mill. is a very fragrant member of Rosaceae family, exhibiting strong antioxidant and antimicrobial activity. In this study, in vitro cell cultures from Rosa damascena Mill. flower petals were established and the effects of precursor L-phenylalanine, the elicitor methyl jasmonate and light/dark treatments on the accumulation of characteristic rose volatile compounds, tocopherols and $\beta$-carotene in addition to the antibacterial activity of petal callus extracts were investigated with Solid-Phase Microextraction Combined with Gas Chromatography-Mass Spectrometry (GC-MS). The amount
\end{abstract}

of $\beta$-pinene increased by 236 times when $500 \mu \mathrm{M}$ Phe was added to the culture medium or under light treatment. Strong antibacterial activity from petal callus extracts, up to 2.6fold compared to amikacin as well as original petal tissues, was obtained under dark treatment for P. aeruginosa ATCC 27853 and S. aureus ATCC 25923. These results revealed that petal callus extracts are sources of natural antioxidants and antibacterial compounds.

Keywords: Rosa damascena Mill., flower petals, callus, secondary metabolite, antibacterial activity
Pinar Olgunsoy, Seyhan Ulusoy

Suleyman Demirel University, Faculty of Arts and Sciences, Department of Biology

Ufuk Celikkol Akcay

Suleyman Demirel University, Faculty of Agriculture, Department of Agricultural Biotechnology

Corresponding Author:

Seyhan Ulusoy

e-mail: seyhanulusoy@sdu.edu.tr

Submitted / Gönderilme: 13.03.2017
Accepted / Kabul: $\quad 27.04 .2017$

Revised / Düzeltme: 18.04.2017

\section{Introduction}

Rosa damascena Mill. (Damask rose) is one of the most industrially important member of Rosaceae family. Damask rose essential oil, rose water, and rose absolute obtained from purification processes are used in cosmetics and perfumery industries (1) and due to its non-toxic nature also considered as a potential antioxidant and antimicrobial additive in food industry $(2,3)$. The analysis of the chemical compositions of the extracts revealed that the terpenoids citronellol and geraniol were the major compounds (55\%) of rose essential oil and hydrosol, while phenylethyl alcohol (78.38\%) was the main constituent of rose absolute (4). The rose products also showed high concentrations of tocopherols, carotenoids and other phenolic compounds. A recent study performed for the determination of polyphenols and volatile components of damask rose using supercritical $\mathrm{CO}_{2}$ extraction also reported that the most abundant in the flower extract were 2-phenylethanol (44.16\%) and aliphatic hydrocarbons such as nonadecane (30.66\%) and eneicosane (4.39\%) (5).

Complex mixture of metabolites are responsible for the wide range of biochemical activities of damask rose extracts including antioxidant, antimicrobial, analgesic and 
anti-inflammatory $(4,6,7)$. However the commercial supply of these active metabolites is limited to the field grown damask rose petals hand picked in a restricted season of average two months. Plant tissue cultures posses a potential for the continuous and high level production of complex metabolites in a controlled environment, independent from regional, seasonal and somatic variations and unaffected from biotic or abiotic stresses.

Various elicitor substances and precursor feeding strategies are used for the increased production of secondary metabolites in plant tissue cultures. Jasmonic acid and its esters, especially methyl jasmonate are the most commonly applied stress related elicitors (8). They are inducers of terpenoid metabolism (9) and they also activate phenylalanine ammonia lyase "the enzyme that catalyzes the first step in the shikimic acid pathway" leading to the production of a variety of secondary metabolites (10). Phenylalanine is an amino acid precursor of the phenylpropanoide pathway leading to the formation of phenolic acids, flavonoids and other phenolic compounds (11). This amino acid successfully used to increase the metabolite production in vitro in many different plant cultures (12).

Some polar and volatile compounds of damask rose cultures have already been investigated in plant tissue cultures as free suspension, in two-phase system and in bioreactor and the researchers concluded that the main components were hydrocarbons, fatty acids, and their esters, however their amounts and distribution were different in different culture systems (13). This particular study did not concentrate on potential antioxidant and antimicrobial compounds of damask rose and the cultures were not originated from petal tissues, but from stem explants. In another study, ethanolic extracts of plant cell cultures of lavender (Lavandula vera) and rose (Rosa damascena) have been examined as potential food antioxidants (2). The $L$. vera cell culture extracts quenched stable radicals and inhibited lipid oxidation in model systems more efficiently than the $R$. damascena Mill. cell culture extracts. However in that study, the cell cultures of damask rose were also obtained from stem explants and not from flower petals, where the active metabolites were extracted for industrial purposes. Single report of petal culture is present in the literature and it compares callus derived from axillary bud, leaf, petal, stem, calyx and root tissues in terms of 2-phenylethanol production (14). The study reports 2-phenylethanol production only in axillary bud derived calli under specific culture conditions in levels of $6 \%$ of original petal tissue.
According to our knowledge, there is no literature data on the elicitation and the precursor feeding of $R$. damascena Mill. in vitro petal cell cultures. This study was performed to investigate the influence of the precursor $L$-phenylalanine (Phe), the elicitor methyl jasmonate (MeJA) and light/dark treatments on the accumulation of characteristic rose volatile compounds, tocopherols and $\beta$-carotene in addition to the antibacterial activity of petal cell cultures.

\section{Materials and methods}

\subsection{Preparation of cell cultures}

R. damascena petals were collected from research plantations located in Suleyman Demirel University, Damask Rose and Rose Products Research Center (GULAR), Isparta, Turkey. The petals of $R$. damascena Mill. flowers were removed and surface sterilized by rinsing with $70 \%$ ethanol and keeping in $5 \%$ sodium hypochlorite for $2 \mathrm{~min}$, which was followed by three rinses with sterile distilled water. The petals were placed on MS basal medium (15) with B5 vitamins including $4 \%$ sucrose, $2 \mathrm{mg} / \mathrm{L}$ 1-naphthaleneacetic acid (NAA) and $0.5 \mathrm{mg} / \mathrm{L}$ 6-benzyladenine (BA), solidified with $0.8 \%(\mathrm{w} / \mathrm{v})$ agar. The optimum hormone concentration was determined according to a previous cell culture optimization study in which various plant hormones were tested in various combinations. The explants were cultured at $25^{\circ} \mathrm{C}$ in dark for 28 days. Following 3 subcultures conducted at the same conditions to increase culture biomass, the cell cultures were placed in the same media containing two different concentrations of an elicitor methyl jasmonate (1 and $5 \mu \mathrm{M})$ and a precursor phenylalanine $(100$ and $500 \mu \mathrm{M})$ for 21 days. Following 2 subcultures to increase culture biomass under continuous elicitation, the cultures were divided for the application of dark or $16 \mathrm{~h}$ light $\left(400 \mu \mathrm{mol} \mathrm{m} \mathrm{m}^{-2}\right) / 8 \mathrm{~h}$ dark photo-cycle treatments which continued for 21 days.

\subsection{Preparation of Cell culture Extracts}

Cell culture samples were extracted with hexane and ethyl alcohol for $12 \mathrm{~h}$ at a solid-to-solvent ratio of 1:5 (w/v). The cell culture extracts were sterilized by filtration through a $0.45-\mu \mathrm{m}$ membrane filter.

\subsection{Bacterial Strains}

Pseudomonas aeruginosa ATCC 27853 and Staphylococcus aureus ATCC 25923 were obtained from the Department of Biology, Suleyman Demirel University, Isparta, Turkey. 
Bacterial cultures were stored on appropriate agar slants at $4^{\circ} \mathrm{C}$ during whole study and used as stock cultures.

\subsection{Antibacterial Assay}

Antibacterial activities of cell culture extracts were carried out by well diffusion assays against Pseudomonas aeruginosa ATCC 27853 and Staphylococcus aureus ATCC 25923. Turbidity of the cultures were adjusted to McFarland no 0.5 standard. Five $\mathrm{ml}$ of molten LB agar $(0.7 \% \mathrm{w} / \mathrm{v})$ were inoculated with $100 \mu \mathrm{L}$ of suspension containing $10^{8} \mathrm{CFU} /$ $\mathrm{ml}$ of bacteria and immediately poured over the prewarmed plates. $50 \mu \mathrm{L}$ of the extracts were pipetted into the punchedwells in the solidified $\mathrm{MH}$ agar. The plates were incubated for $24-48 \mathrm{~h}$ at $37^{\circ} \mathrm{C}$. Antibacterial activity was determined by the diameter of inhibition zones $(\mathrm{mm})$ around the wells. Methanol was used as a negative control and Amikacin was used as a positive control. Studies were performed in triplicate.

\subsection{Analysis of Volatile compounds of Cell culture Extracts with Solid-Phase Microextraction Combined with Gas Chromatography-Mass Spectrometry(GC-MS)}

A solid-phase microextraction (SPME: Fused silica SPME fiber CAR/PDMS) combined with gas chromatograph-mass spectrometer system(Shimadzu (Japan) GC 2010 PLUS) was applied to the determination of the volatile compounds of cell culture extracts. Separations were carried out by a Restek Rx-5Sil MS $30 \mathrm{~m}^{\star} 0.25 \mathrm{~mm}, 0.25 \mu \mathrm{m}$. Helium (99.999\%), was used as carrier gas at a constant head pressure of 10 p.s.i (1 p.s.i $=6894.76 \mathrm{~Pa})$. Injection volume was $1 \mu \mathrm{L}$. The GC oven was programmed as follows: the initial column temperature was $60^{\circ} \mathrm{C}$, the column was heated to $220^{\circ} \mathrm{C}$ at a rate of $2^{\circ} \mathrm{C}$ min- 1 and held at $220^{\circ} \mathrm{C}$ for $20 \mathrm{~min}$. The GC-MS interface and injector were kept at 250 and $240^{\circ} \mathrm{C}$, respectively. The mass spectrometer was run in the electron impact mode at $70 \mathrm{eV}$.

\subsection{Determination of Tocopherol Isomers and $\beta$-Carotene of Cell culture Extracts with HPLC}

In the tocopherol analysis, the HPLC method of Lampi et al. (16) was modified. Quantification of tocopherols ( $\alpha-$, $\beta$-, $\gamma$ - and $\delta$-tocopherol) were carried out with a Shimadzu LC-20AT prominence System controller (Kyoto, Japan), SIL-20AC prominence Autosampler, LC-20AT prominence pump and RF-10AXL Fluorescence Detector (Ex 295 nm,
Em $330 \mathrm{~nm})$ for tocopherols. The Luna Silica $\left(250^{\star} 4.6 \mathrm{~mm}\right)$ $5 \mu$ (Supelco, Inc., Bellefonte, PA) column was used. The mobile phase was consisted of heptane/THF (95/5) (v/v) at a flow rate of $1.2 \mathrm{ml} / \mathrm{min}$ and the injection volume was 10 $\mu \mathrm{L}$. For carotene analysis, detection and quantification were carried out with Shimadzu SCL-10Avp System controller (Kyoto, Japan), LC-10ADvp pump, CTO-10ACvp column oven and SPD-M10Avp (Diode Array Detector (450nm) for beta carotene. The YMC-Pack ODS-AM $(250 * 4.6 \mathrm{~mm}$, $5 \mu)$ column was used. The mobile phase was consisted of Methanol/ACN/THF (73/20/7), (v/v/v) at a flow rate of 1 $\mathrm{ml} / \mathrm{min}$ and the injection volume was $20 \mu \mathrm{L}$. The amount of tocopherols and carotene in the cell culture extracts were calculated as ppm using external calibration curves.

\section{Results}

After the culture period, cells accumulated as 30-50 grams in total mass per petri plate. Growth of fast dividing friable calli slowed down when moved to light and the texture of the calli changed to become harder. Green and pink pigmentation also developed on the close and rear surfaces of the calli from the light source (Figure 1).

\section{GC-MS analysis of cell culture extracts}

Myrcene, benzyl alcohol, dimethyl styrene, linalool, phenyl ethyl alcohol, citronellal, citronellol, linalyl acetate, geranial, citronellyl acetate, methyl eugenol and heneicosane were the compounds found in rose petals at various concentrations, while could not be detected in petal cell cultures, therefore not included in Table 1. In cultured petal cells, terpeneoids alpha/beta pinene and nonterpene compounds phenylethene, caproaldehyde and benzaldehyde replaced the most common volatile monoterpene compounds of rose flowers, in particular linalool, citronellol, nerol, geraniol and phenylethanol. Amounts of caproaldehyde were 36 and 25-fold higher in dark or light treated control cultures, respectively compared to original petal tissue, while higher increases around 55fold were obtained in light treated $5 \mu \mathrm{M}$ MeJA elicited and $100 \mu \mathrm{M}$ Phe fed cultures. Compared to petals, levels of styrene were around 50-fold higher in cultured cells and 75fold increase was detected in $100 \mu \mathrm{M}$ Phe fed culture cells. Benzaldehyde content increased 8-fold in $500 \mu \mathrm{M}$ Phe fed, dark treated cell cultures. Although several treatments ended terpenoid pinene production in cultured cells, cell cultures usually produced more alpha and beta pinene which reached up to 236-fold for beta pinene in $500 \mu \mathrm{M}$ Phe fed cultures 

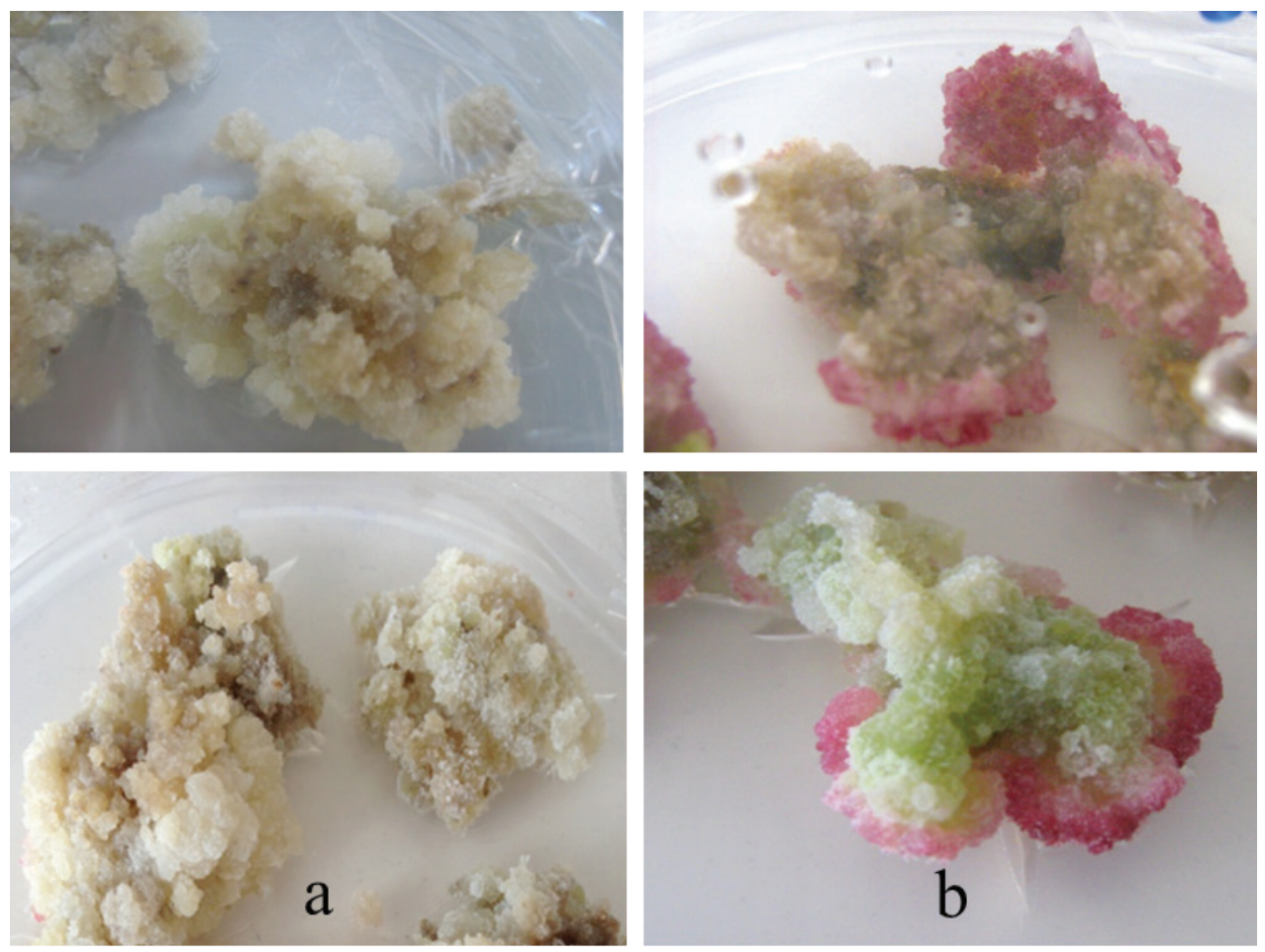

Figure 1. Dark grown rose petal cell cultures (a) and light treated petal cell cultures (b) grown on $4 \mathrm{mg} / \mathrm{L} \mathrm{NAA}$ and $1 \mathrm{mg} / \mathrm{L}$ BA containing MS media showing different pigmentation and textural characteristics.

Table 1. GC-MS analysis of petal volatile compounds in petal cell cultures under different treatments.

\begin{tabular}{|c|c|c|c|c|c|c|c|c|c|c|c|c|}
\hline Compounds & $\begin{array}{c}\text { Retention } \\
\text { time (min.) }\end{array}$ & $\begin{array}{c}\text { Rose } \\
\text { petal (\%) }\end{array}$ & $\begin{array}{c}\text { Control } \\
\text { (D) }\end{array}$ & $\begin{array}{c}\text { Control } \\
\text { (L) }\end{array}$ & $\begin{array}{l}\text { MeJA1 } \\
\text { (D) }\end{array}$ & $\begin{array}{c}\text { MeJA1 } \\
(\mathrm{L})\end{array}$ & $\begin{array}{l}\text { MeJA5 } \\
\text { (D) }\end{array}$ & $\begin{array}{c}\text { MeJA5 } \\
(\mathrm{L})\end{array}$ & $\begin{array}{c}\text { Phe } 100 \\
\text { (D) }\end{array}$ & $\begin{array}{c}\text { Phe } 100 \\
\text { (L) }\end{array}$ & $\begin{array}{c}\text { Phe } 500 \\
\text { (D) }\end{array}$ & $\begin{array}{c}\text { Phe } 500 \\
\text { (L) }\end{array}$ \\
\hline Caproaldehyde & 4.025 & 0.48 & 17.41 & 11.82 & 3.05 & 22.14 & 10.88 & 26.47 & 4.27 & 25.76 & 11.33 & 6.96 \\
\hline Styrene & 6.517 & 0.47 & 25.39 & 22 & 4.61 & 28.29 & 2.12 & 26.03 & 28.24 & 35.23 & 8.95 & 4.43 \\
\hline Alpha pinene & 7.963 & 1.18 & 18.07 & 7.56 & 18.17 & 18.43 & 22.37 & 12.44 & * & 15.24 & 4.26 & 11.03 \\
\hline Benzaldehyde & 8.923 & 1.93 & 6.35 & * & 0.56 & 0.68 & * & 0.48 & 1.06 & * & 15.87 & * \\
\hline Beta pinene & 9.528 & 0.20 & 2.57 & 33.28 & 2.54 & * & 2.86 & 0.64 & * & 3 & * & 47.25 \\
\hline Limonene & 11.517 & 0.23 & 0.86 & * & 0.29 & * & * & * & 0.61 & * & * & * \\
\hline Terpinolene & 13.678 & 1.26 & * & 0.83 & * & * & * & * & * & * & * & 1.57 \\
\hline Tetradecane & 25.270 & 0.05 & * & * & * & * & * & * & 0.13 & * & * & * \\
\hline Pentadecane & 28.544 & 1.06 & 12.2 & * & * & * & * & * & 1.39 & * & * & * \\
\hline Hekzadecane & 31.632 & 0.10 & * & * & * & 1.03 & * & * & 2.22 & * & * & * \\
\hline Heptadecane & 34.578 & 0.93 & 4.53 & * & * & 1.18 & * & * & 1.11 & * & * & * \\
\hline Nonadecane & 40.038 & 1.59 & 12.33 & 2.45 & * & 2.38 & * & 1.05 & * & 2.14 & * & 2.61 \\
\hline Eicosane & 42.562 & 0.05 & * & 6.59 & * & 5.49 & * & 2.49 & * & 4.91 & * & 7.41 \\
\hline
\end{tabular}

$\mathrm{D}$ and $\mathrm{L}$ represents dark and light treatments; MeJA and Phe are the abbreviations for elicitor methyl jasmonate and precursor phenylalanine, respectively, specified with their applied concentrations in $\mu \mathrm{M},{ }^{*}$ : not detected..

after light treatment. Terpenoid limonene and terpinolene, hydrocarbon tetradecane, pentadecane, hekzadecane and heptadecane levels were usually undetectable in cell cultures, although increases in concentration up to 1.25-22fold were detected in various treatments, particularly dark treated control and $100 \mu \mathrm{M}$ Phe fed cell cultures. Levels of nonadecane and eicosane were undetectable under dark and MeJA/Phe treatments. The levels increased up to 148 -fold (500 $\mu \mathrm{M}$ Phe fed cultures for eicosane) in light treated cell cultures. 


\section{HPLC Analysis of tocopherol isomers and carotene levels of cell culture extracts.}

$\beta$-carotene and $\alpha$-, $\beta$-, $\gamma$ - and $\delta$-tocopherol concentrations of cell culture extracts were simultaneously measured using a reverse phase HPLC system. $\alpha$-tocopherol levels were 2 (Phe $100 \mu \mathrm{M})$ to 4 -fold (MeJA $5 \mu \mathrm{M}$ ) higher in all dark treated and elicitor/precursor supplemented cultures when compared to original petal tissue, while light treatment decreased a-tocopherol levels in all cultures tested (Table 2). Also the elicitor/precursor treatments increased $\alpha$-tocopherol levels of cell cultures when compared to control cultures. Levels of $\beta$-tocopherol in elicitor/precursor treated and control cell cultures developed at dark were always lower than the original petal tissue, while $\beta$-tocopherol was nonexistent in light treated cultures independent from the elicitor/precursor application. $\delta$-Tocopherol was present in low concentrations $(0.016 \mathrm{ppm})$ in the original petal tissue, however it was not detected in any of the cell culture applications. $\gamma$-Tocopherol was nonexistent in the original petal tissue as well as in all of the cell culture applications (data not shown). $\beta$-Carotene levels in cell cultures were also lower or nonexistent (under light and elicitor/precursor treatments) when compared to the original petal tissue.

\section{Antibacterial effects of cell culture extracts}

The results of antibacterial screening tests of cell culture extracts against $P$. aeruginosa ATCC 27853 and S. aureus ATCC 25923 using well diffusion techniques are depicted in Figure 2 and Table 3. The cell culture extracts exhibited inhibition zones ranging from $11 \mathrm{~mm}$ to $42 \mathrm{~mm}$ in diameter, which is $16 \mathrm{~mm}$ and $17 \mathrm{~mm}$ in rose petal extracts. Control and $1 \mu \mathrm{M}$ MeJA treated cell culture extracts developed in dark exhibited the widest inhibition zones in comparison with the antibiotic Amikacin. Except $5 \mu \mathrm{M}$ MeJA elicited and $500 \mu \mathrm{M}$ Phe fed cultures, dark treated cell culture extracts showed more significant inhibitory activities against $P$. aeruginosa ATCC 27853 and against S. aureus ATCC 25923 than the light treated extracts.

\section{Elicitation and precursor feeding}

Elicitor methyl jasmonate and precursor phenylalanine, succesfully increased the levels of various secondary metabolites in different plant cell culture systems $(17,18)$. In $R$. damascena cell cultures, significant effects of MeJA and Phe were detected for the increased accumulation of a-tochopherol, caproaldehyde, styrene, alpha and beta
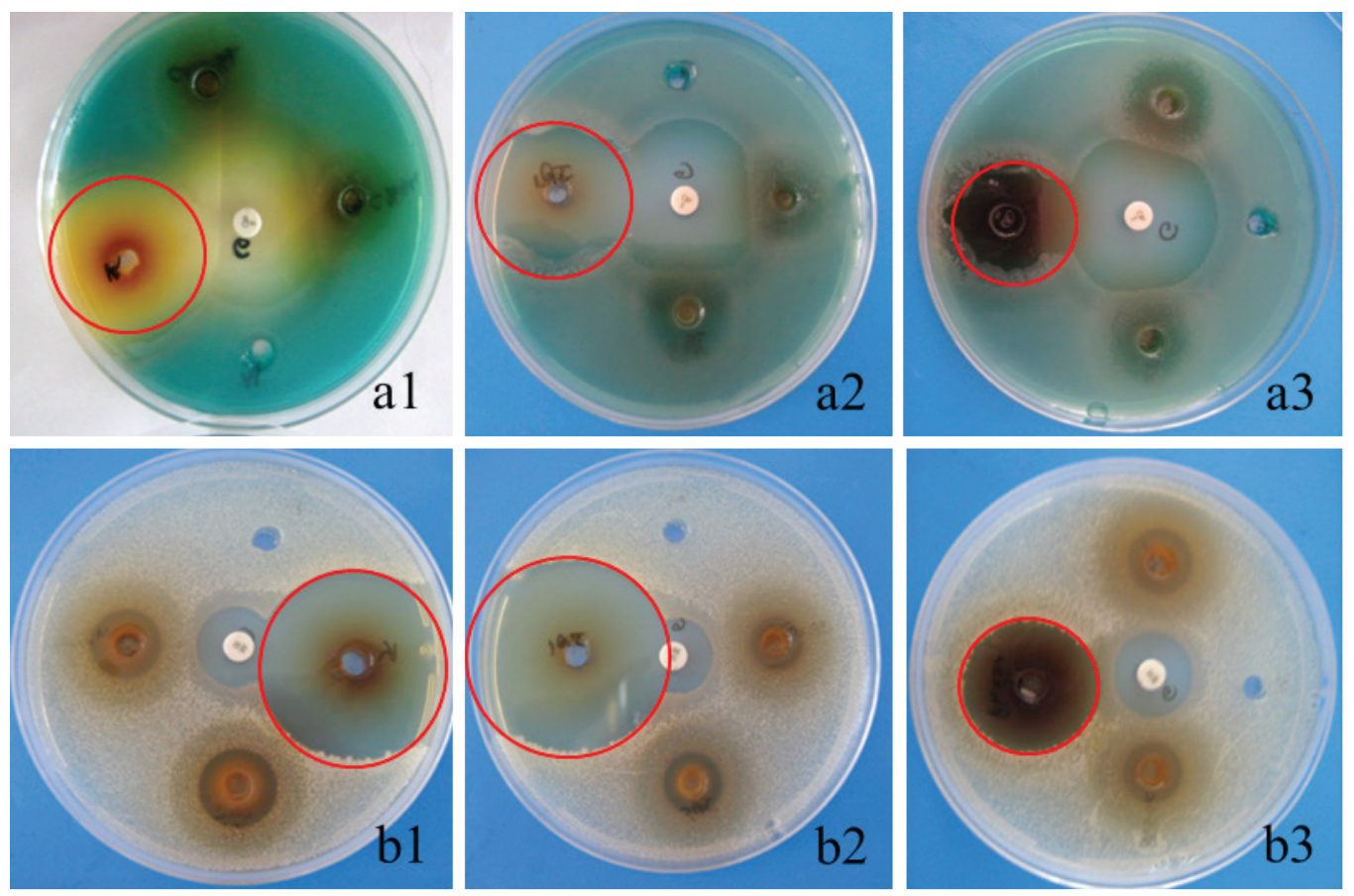

Figure 2. Anti-bacterial activities of dark treated cell culture extracts against P. aeruginosa ATCC 27853 control (a1), MS medium supplemented with $1 \mu \mathrm{M}$ MeJA (a2), supplemented with $100 \mu \mathrm{M}$ Phe (a3); against S. aureus ATCC 25923 control (b1), MS medium supplemented with $1 \mu \mathrm{M}$ MeJA (b2), supplemented with $100 \mu \mathrm{M}$ Phe (b3). 
Table 2. Tocopherol and carotene levels of cell culture extracts.

\begin{tabular}{ccccc}
\hline Sample name & $\boldsymbol{\alpha}$ - tocopherol $(\mathbf{p p m})$ & $\boldsymbol{\beta}$-tocopherol $(\mathbf{p p m})$ & $\boldsymbol{\delta}$-tocopherol $(\mathbf{p p m})$ & $\beta$-carotene $(\mathbf{p p m})$ \\
\hline Rose petal extract & $4.82 \pm 0.03$ & $0.32 \pm 0.03$ & $0.016 \pm 0.001$ & $0.94 \pm 0.01$ \\
Control (D) & $3.20 \pm 0.17$ & $0.015 \pm 0.003$ & ND & $0.070 \pm 0.001$ \\
Control (L) & $1.00 \pm 0.02$ & ND & ND & $0.060 \pm 0.001$ \\
MeJA 1 (D) & $12.8 \pm 0.42$ & $0.063 \pm 0.006$ & ND & $0.18 \pm 0.01$ \\
MeJA 1 (L) & $0.40 \pm 0.02$ & ND & ND & $0.17 \pm 0.01$ \\
MeJA 5 (D) & $19.9 \pm 0.56$ & $0.074 \pm 0.007$ & ND & ND \\
MeJA 5 (L) & $0.30 \pm 0.02$ & ND & ND & $0.07 \pm 0.001$ \\
Phe 100(D) & $11.0 \pm 0.41$ & $0.052 \pm 0.005$ & ND & ND \\
Phe 100(L) & $0.50 \pm 0.02$ & ND & ND & $0.15 \pm 0.01$ \\
Phe 500(D) & $11.9 \pm 0.43$ & $0.055 \pm 0.005$ & ND & ND \\
Phe 500(L) & $0.8 \pm 0.02$ & ND & \\
\hline
\end{tabular}

$\mathrm{D}$ and L represents dark and light treatments; MeJA and Phe are the abbreviations for elicitor methyl jasmonate and precursor phenylalanine, respectively, specified with their applied concentrations in $\mu \mathrm{M}$.

pinene either at light or dark, depending on the treatment. Antibacterial effects of culture extracts increased by $1 \mu \mathrm{M}$ MeJA treatment and $100 \mu \mathrm{M}$ Phe treatment in dark, however the activity also increased in dark treated control cultures making the elicitor and feeding treatments dispensable, while making the dark treatment an essential, for obtaining antimicrobial activity.

\section{Light}

Light provides the basics for plant growth and development and controls various aspects of primary and secondary metabolism. Light was used as an inducer of secondary metabolism in various studies and increased paclitaxel production in Taxus cuspidata cells (19), anthocyanins in Perilla frutescens (20), caffeic acid derivatives in Echinacea angustifolia (21), phenolics of Hypericum hookerianum (22) and isoflavones of Psoralea corylifolia (23). Our study also showed the very different nature of light and dark treated Rosa damascena petal cell cultures in terms of the levels of volatile compounds, tocopherols, $\beta$-carotene and the diameters of bacterial inhibition zones produced by cell extracts. Dark treated control and $1 \mu \mathrm{M}$ MeJA elicited culture extracts increased the diameters about 2,5-fold compared to light treated cultures and also compared to original petal tissues. Dark treatments were also superior in terms of tocopherol production. Light usually induced caproaldehyde, styrene, and $\alpha / \beta$-pinene synthesis in MeJA elicited and Phe

Table 3. Inhibition zone diameters of cell culture extracts against P. aeruginosa ATCC 27853 and S. aureus ATCC 25923.

\begin{tabular}{lcc}
\hline & \multicolumn{2}{c}{ Inhibition zone diameter(mm) } \\
Sample name & P. aeruginosa ATCC 27853 & S. aureus ATCC 25923 \\
\hline Rose petal extract & $17 \pm 0.6$ & $16 \pm 0.6$ \\
Control (D) & $40 \pm 0.6$ & $40 \pm 0.7$ \\
Control (L) & $14 \pm 0.6$ & $15 \pm 0.7$ \\
MeJA 1(D) & $40 \pm 0.6$ & $42 \pm 1.3$ \\
MeJA 1(L) & $12 \pm 0.6$ & $12 \pm 0.5$ \\
MeJA 5(D) & $*$ & $13 \pm 0.6$ \\
MeJA 5(L) & $13 \pm 0.6$ & $13 \pm 0.6$ \\
Phe 100(D) & $26 \pm 1.0$ & $28 \pm 0.6$ \\
Phe 100(L) & $13 \pm 0.6$ & $15 \pm 0.6$ \\
Phe 500(D) & $*$ & $11 \pm 0.6$ \\
Phe 500(L) & $16 \pm 1.0$ & $16 \pm 0.6$ \\
Amikacin & $17 \pm 0.6$ & $16 \pm 0.6$ \\
Methanol & $*$ & $*$ \\
\hline
\end{tabular}

$\mathrm{D}$ and $\mathrm{L}$ represents dark and light treatments; MeJA and Phe are the abbreviations for elicitor methyl jasmonate and precursor phenylalanine, respectively, specified with their applied concentrations in $\mu \mathrm{M},{ }^{*}$ : no inhibition zone. 
fed cell cultures and also $\beta$-pinene in control cultures. Light treatment was significantly superior for monoterpenoid $\alpha / \beta$ pinene synthesis, compared to dark treatments in Phe fed cultures.

\section{Antibacterial activity}

Volatile benzoic acid (BA) compounds confer antimicrobial activities to valuable reproductive tissues and are involved in plant defense $(24,25)$. Benzaldehyde, which is not a very widely investigated volatile BA compound, possibly possesses antibacterial activity since it constitutes $80 \%$ of Hemidesmus indicus root extracts and the extracts are common remedies for syphilis, fever and bronchitis in Indian traditional medicine as reported by Sreekumar et al. (26). In our study, dark treated control cell cultures possessed 3-fold more and $500 \mu \mathrm{M}$ Phe fed cultures possessed 8-fold more benzaldehyde compared to original rose petals. Dark treated control cell culture extracts exhibited strong antibacterial activity, whereas $500 \mu \mathrm{M}$ Phe fed cultures exhibited similar or less activity compared to petal extracts which might be explained with changing effects of complex combination of bioactive compounds, which are lacking or less in the latter, including caproaldehyde, styrene, $\alpha$ and $\beta$-pinene, limonene, pentadecane, heptadecane and nonadecane.

\section{Conclusion}

This study suggest that, callus extracts obtained from the $R$. damascena Mill. petals, have potential to be used as a source of natural antioxidants (tocopherols, carotenes etc.) and antibacterial (benzaldehyde, pinene etc.) molecules without time restrictions. In addition, synthetic antioxidants suffer from several drawbacks, callus extracts of $R$. damascena Mill. petals may be alternative as a preservative for cosmetic industries.

\section{Acknowledgement}

This work was supported by the Suleyman Demirel University under Grant “3540-YL1-13”.
Rosa damascena Mill. petal kallus kültürlerinin antibakteriyel etkileri ve metabolit üretimi

\section{ÖZ}

Rosa damascena Mill. Rosaceae familyasının güzel kokulu çiçekleri olan bir üyesi olup, güçlü antioksidan ve antimikrobiyal özelliğe sahiptir. Bu çalışmada Rosa damascena Mill. çiçek petallerinden in vitro hücre kültürü yapılmış, bu kültürlerden hazırlanan ekstrelerde $L$-fenilalanin, metil jasmonat, $1 s ̧ 1 \mathrm{k} /$ karanlık uygulamasının gül uçucu bileşenleri, tokoferol, $\beta$-karoten üretimine etkisi ve antibakteriyel özellikleri incelenmiştir. Petal hücre ekstrelerinde, terpeneoidler (alfa/beta pinen) fenileten, kaproaldehit and benzaldehit bulunduğu SPME/GC-MS ile tespit edilmiştir. Işık veya $500 \mu \mathrm{M}$ fenilalanin uygulaması ile beta pinen miktarının 236 kat arttığı belirlenmiştir. Karanlık uygulaması ile kültür ekstrelerinin antibakteriyel etkilerinin P. aeruginosa ATCC 27853 ve S. aureus ATCC 25923 için kanamisine göre 2.6 kat arttığı belirlenmiştir. $\mathrm{Bu}$ sonuçlar, petal kallus ekstrelerinin doğal antioksidan ve antibakteriyel moleküller içerdiğini göstermektedir.

Anahtar kelimeler: Rosa damascena Mill., çiçek petalleri, kallus, sekonder metabolit, antibakteriyel aktivite

\section{References}

1. Baydar H. Oil-bearing rose (Rosa damascena Mill.) cultivation and rose oil industry in Turkey. Euro Cosmetics 2006; 14: 13.

2. Kovatcheva-Apostolova EG, Georgiev MI, Ilieva MP, Skibsted LH, Rødtjer A, Andersen ML. Extracts of plant cell cultures of Lavandula vera and Rosa damascena as sources of phenolic antioxidants for use in foods. Eur Food Res Technol 2008; 227: 1243-9.

3. Sagdiç O, Baydar N, Baydar H. Note: Antioxidant and antibacterial activities of Rosa damascena flower extracts. Food Sci Technol Int 2004; 10: 277-81.

4. Ulusoy S, Boşgelmez-Tinaz G, Seçilmiş-Canbay H. Tocopherol, carotene, phenolic contents and antibacterial properties of rose essential oil, hydrosol and absolute. Curr Microbiol 2009; 59: 554-8.

5. Da Porto C, Decorti D, Natolino A. Application of a supercritical $\mathrm{CO} 2$ extraction procedure to recover volatile compounds and polyphenols from Rosa damascena. Separ Sci Technol 2015; 50: 1175-80.

6. Basim E, Basim H. Antibacterial activity of Rosa damascena essential oil. Fitoterapia 2003; 74: 394-6.

7. Achuthan C, Babu B, Padikkala J. Antioxidant and hepatoprotective effects of Rosa damascena. Pharm Biol 2003; 41: 357-61.

8. Matkowski A. Plant in vitro culture for the production of antioxidants-a review. Biotechnol Adv 2008; 26: 548-60.

9. Roberts SC. Production and engineering of terpenoids in plant cell culture. Nature Chem Biol 2007; 3: 387-95.

10. Namdeo A. Plant cell elicitation for production of secondary metabolites: a review. Pharmacogn Rev 2007; 1: 69-79. 
11. Skrzypczak-Pietraszek E, Słota J, Pietraszek J. The influence of L-phenylalanine, methyl jasmonate and sucrose concentration on the accumulation of phenolic acids in Exacum affine Balf. f. ex Regel shoot culture. Acta Biochim Pol 2014; 61: 47-53.

12. Arora R. Medicinal plant biotechnology: CABI; 2010.

13. Pavlov A, Popov S, Kovacheva E, Georgiev M, Ilieva M. Volatile and polar compounds in Rosa damascena Mill 1803 cell suspension. J Biotechnol 2005; 118: 89-97.

14. Banthorpe DV, Branch SA, Poots I, Fordham WD. Accumulation of 2-phenylethanol by callus derived from leafbud of Rosa damascena. Phytochem 1988; 27: 795-801.

15. Murashige T, Skoog F. A revised medium for rapid growth and bio assays with tobacco tissue cultures. Physiol Plant 1962; 15: 473-97.

16. Lampi A-M, Kataja L, Kamal-Eldin A, Vieno P. Antioxidant activities of $\alpha$-and $\gamma$-tocopherols in the oxidation of rapeseed oil triacylglycerols. J Am Oil Chem Soc 1999; 76: 749-55.

17. Creelman RA, Mullet JE. Biosynthesis and action of jasmonates in plants. Annu Rev Plant Biol 1997; 48: 355-81.

18. Gala R, Mita G, Caretto S. Improving a-tocopherol production in plant cell cultures. J Plant Physiol 2005; 162: 782-4.

19. Yamamoto S, Hayashi S, Furusaki S, Shioya S. 5-Aminolevulinic acid promotes callus growth and paclitaxel production in light-grown Taxus cuspidata suspension cultures. Eng Life Sci 2015; 15: 116-21.
20. Zhong Jj, Seki T, Kinoshita Si, Yoshida T. Effect of light irradiation on anthocyanin production by suspended culture of Perilla frutescens. Biotechnol Bioeng 1991; 38: 653-8.

21. Guarnerio CF, Fraccaroli M, Gonzo I, Pressi G, Dal Toso R, Guzzo F, Levi M. Metabolomic analysis reveals that the accumulation of specific secondary metabolites in Echinacea angustifolia cells cultured in vitro can be controlled by light. Plant Cell Rep 2012; 31: 361-7.

22. Sooriamuthu S, Varghese RJ, Bayyapureddy A, John SST, Narayanan R. Light-induced production of antidepressant compounds in etiolated shoot cultures of Hypericum hookerianum Wight \& Arn.(Hypericaceae). Plant Cell, Tissue Organ Cult (PCTOC) 2013; 115: 169-78.

23. Shinde AN, Malpathak N, Fulzele DP. Determination of isoflavone content and antioxidant activity in Psoralea corylifolia L. callus cultures. Food Chem 2010; 118: 128-32.

24. Dudareva N, Pichersky E, Gershenzon J. Biochemistry of plant volatiles. Plant Physiol 2004; 135: 1893-1902.

25. Köllner TG, Lenk C, Zhao N, Seidl-Adams I, Gershenzon J, Chen F, Degenhardt J. Herbivore-induced SABATH methyltransferases of maize that methylate anthranilic acid using S-adenosyl-L-methionine. Plant Physiol 2010; 153: 1795-1807.

26. Sreekumar S, Seeni S, Pushpangadan P. Micropropagation of Hemidesmus indicus for cultivation and production of 2-hydroxy 4-methoxy benzaldehyde. Plant Cell, Tissue Organ Cult 2000; 62: 211-8. 